\title{
Peran Mediasi Persepsi Harga Terhadap Kualitas Pengalaman dan Kepuasan Wisatawan
}

\author{
Echo Perdana Kusumah ${ }^{1}$, Ratih Hurriyati ${ }^{2}$, Hamsani Hamsani ${ }^{3}$ \\ ${ }^{1}$ Sekolah Pascasarjana, Universitas Pendidikan Indonesia, Indonesia, ${ }^{2}$ Sekolah Pascasarjana, Universitas Pendidikan \\ Indonesia, Indonesia, ${ }^{3}$ Fakultas Ekonomi, Universitas Bangka Belitung, Indonesia
}

Tourist experiences can provide an assessment of a destination by tourists. In the context of island destinations, this study aims to explore deeper the quality of tourist experiences, price perceptions, and tourist satisfaction. The quality of the tourist experience consists of various variables, including escapist, pleasure, relaxation and involvement. A total of 157 samples were obtained through online convenience sampling method for tourists who have visited Belitung Island. Respondents are devoted to tourists who are located outside Belitung Island to avoid biased answers from local residents. Structural Equation Model (SEM) was applied in this study. The results show that only the involvement factor in the quality of tourist experience can influence price perception. Perceptions of prices can indirectly mediate the quality of tourist experiences, except for relaxation. Regardless of the fact that visitors consider the price to be outrageous (expensive or unsuitable), they will still create a positive assessment of the destination if they can involve in the decisionmaking process. In turn they will be satisfied with their experiences.

OPEN ACCESS

ISSN 2528-4649 (online) ISSN 2338-4409 (print)

Reviewed by:

Wisnu Panggah Setiyono \& Nurul

Qomariah \& Vinola Herawaty

${ }^{*}$ Correspondence:

Received: 22 Juli 2020 Accepted: 26 Agustus 2020 Published: 30 September 2020

Citation:

Perdana Kusumah E, Hurriyati $R$ and Hamsani $H$ (2020) Peran Mediasi Persepsi Harga Terhadap Kualitas Pengalaman dan Kepuasan

Wisatawan

JBMP. 6:2.

doi: 10.21070/jbmp.v6i2.607
Pengalaman wisata dapat memberikan penilaian terhadap suatu destinasi oleh para wisatawan. Pada konteks destinasi pulau, penelitian ini bertujuan untuk mengekplorasi lebih dalam kualitas pengalaman wisatawan, persepsi harga, dan kepuasan wisatawan. Kualitas pengalaman wisatawan teridiri dari berbagai variabel, diantaranya eskapis, kesenangan, relaksasi dan keterlibatan. Sejumlah 157 sampel berhasil didapatkan melalui metode convenience sampling secara online terhadap para wisatawan yang pernah mengunjungi Pulau Belitung. Responden dikhusukan kepada wisatawan yang berlokasi diluar Pulau Belitung untuk menghindari jawaban bias dari penduduk lokal. Structural Equation Model (SEM) diterapkan pada penelitian ini. Hasil menunjukkan bahwa hanya faktor keterlibatan saja pada kualitas pengalaman wisatawan yang dapat mempengaruhi persepsi harga. Persepsi harga secara tidak langsung dapat memediasi kualitas pengalaman wisatawan, kecuali pada relaksasi. Hal tersebut dapat dimungkinkan bahwa terlepas dari kenyataan bahwa wisatawan berpikir harganya tidak masuk akal (mahal atau tidak pantas), mereka masih akan mengevaluasi destinasi secara positif jika mereka dapat berpartisipasi dalam proses pengambilan keputusan. Hal itu pada gilirannya membuat mereka puas dengan pengalaman wisata mereka. 


\section{PENDAHULUAN}

Hubungan antara kualitas pengalaman, persepsi nilai, dan harga tetap kompleks (Moon \& Han, 2019). Hal tersebut mungkin disebabkan oleh sistem yang belum jelas dalam mempersepsikan pengalaman keseluruhan pada suatu destinasi dan harga. Wisatawan pertama kali terkena harga produk tur, tiket penerbangan, atau kamar hotel. Meskipun wisatawan dapat membandingkan harga dengan harga dari pesaing lain, sulit untuk mengevaluasi harga sebenarnya sebelum mereka benarbenar merasakan destinasi yang dituju. Dalam konteks tersebut, mengeksplorasi hubungan ketidakjelasan antara kualitas pengalaman wisata dan kewajaran harga memerlukan penelitian lebih lanjut. Penelitian sebelumnya menulusuri pengalaman wisata dalam berbagai konteks, seperti wisata malam (Boateng et al., 2018), wisata warisan (Bec et al., 2019), wisata massal (Garau-Vadell et al., 2019), dan wisata budaya (Chen \& Rahman, 2018). Kualitas pengalaman wisata dalam konteks tertentu dapat memainkan peran penting sebagai kontributor kepuasan wisatawan. Penelitian ini bertujuan untuk mengklarifikasi pengaruh kualitas pengalaman aktual wisatawan pada persepsi harga mereka dan pengaruhnya terhadap peningkatan kepuasan wisatawan pada suatu destinasi wisata pulau.

\section{Hubungan Kualitas Pengalaman Wisatawan dan Persepsi Harga}

Kualitas pengalaman wisata dinilai oleh seorang wisatawan berdasarkan evaluasinya terhadap keseluruhan pengalaman di suatu destinasi selama periode waktu tertentu (Kim \& Brown, 2012). Di sekitar pulau, pengunjung dapat mengalami perasaan eskapis dan eksotisme, menciptakan citra pulau itu (Lee et al., 2018). Untuk menggambarkan kualitas pengalaman wisata berdasarkan interaksi pada destinasi pulau, penelitian ini memperkenalkan empat variabel: eskapis, relaksasi, kenikmatan, dan keterlibatan (Hosany \& Witham, 2010; Moon \& Han, 2019). Ketika seseorang menilai kualitas dari apa yang telah dia beli, harga adalah konstruksi yang tidak dapat dipisahkan. Penelitian sebelumnya telah menunjukkan bahwa hubungan antara kualitas produk / jasa dan harga adalah valid (Kaura et al., 2015; Ryu \& Han, 2010). Pada segmen pariwisata, kualitas pengalaman wisata di lingkungan fisik dan sosial keseluruhan destinasi, yang dapat menghasilkan perasaan eskapis, berkontribusi terhadap persepsi positif wisatawan tentang harga (Ali et al., 2016). Ketika wisatawan merasakan kegembiraan dan merasa tersingkir dari kehidupan sehari-hari mereka menganggap pengalaman wisata lebih berharga (Prebensen et al., 2013). Sehingga beberapa hipotesis yang diusulkan sebagai berikut.

H1: Eskapis dapat mempengaruhi secara positif terhadap persepsi harga.

H2: Relaksasi dapat mempengaruhi secara positif terhadap persepsi harga

H3: Kenikmatan dapat mempengaruhi secara positif terhadap persepsi harga.
H4: Keterlibatan dapat mempengaruhi secara positif terhadap persepsi harga

\section{Hubungan Persespi Harga dan Kepuasan Wisatawan}

Harga adalah salah satu faktor utama yang dipertimbangkan wisatawan ketika bepergian dan yang ditanggapi oleh wisatawan dengan sensitif. Harga dapat mencerminkan persepsi objektif dan subyektif terhadap pelanggan (Kim et al., 2012). Aspek obyektif harga mengacu pada sudut pandang harga numerik sedangkan aspek subyektif menunjukkan bagaimana seseorang menginterpretasikan harga melalui evaluasi pengalaman konsumsi (Zeithaml, 1988). Wisatawan juga dapat merasakan aspek numerik harga melalui perbandingan dengan harga pesaing serta dengan pengalaman tur mereka sendiri pada destinasi yang dituju (Murphy \& Pritchard, 1997). Pada konteks penelitian destinasi pulau ini, situasi di mana wisatawan merasakan harga, memberikan mereka kesan harga yang wajar dan kualitas pengalaman wisata (eskapis, relaksasi, kenikmatan, keterlibatan) yang berharga sangat penting. Persepsi wisatawan tentang nilai dapat berbeda sesuai dengan penilaiannya terhadap pertukaran antara pengalaman wisata dan harga yang dibayarkan untuk merasakan suatu pengalaman (Kim et al., 2015). Persepsi harga oleh wisatawan dapat berubah tergantung pada pengalaman nyata mereka di suatu destinasi. Beberapa studi memverifikasi efek positif dari harga yang dirasakan yang berakhir dengan kepuasan pelanggan (Ali et al., 2016; Han \& Hyun, 2015; Kusumah et al., 2019). Pada segmen perhotelan, persepsi harga tamu memiliki efek mediasi antara kinerja hotel dan kepuasan tamu (Chen et al., 2015; Kusumah et al., 2020). Dengan demikian, wisatawan akan puas ketika pengalaman konsumsi mereka berjalan dengan baik dan memenuhi kebutuhan mereka dibandingkan dengan uang yang mereka habiskan. Dengan demikian, hipotesis yang diusulkan sebagai berikut.

H5: Persepsi harga dapat mempengaruhi secara positif dan signifikan terhadap kepuasan wisatawan.

H6a: Persepsi harga dapat memediasi hubungan antara eskapis dan kepuasan wisatawan

H6b: Persepsi harga dapat memediasi hubungan antara relaksasi dan kepuasan wisatawan

H6c: Persepsi harga dapat memediasi hubungan antara kenikmatan dan kepuasan wisatawan

H6d: Persepsi harga dapat memediasi hubungan antara keterlibatan dan kepuasan wisatawan

\section{METODE PENELITIAN}

\section{Sampel dan Pengumpulan Data}

Survei mandiri yang dikelola secara online didistribusikan kepada wisatawan yang telah mengunjungi Pulau Belitung. Pulau tersebut dipilih sebagai destinasi wisata pulau untuk mengumpulkan data karena menarik banyak wisatawan 
nasional dan mancanegara dengan kekayaan sumber daya alam dan gaya hidup lokalnya yang berlimpah. Misalnya, pulau itu memuat banyak wisata bahari berupa pantai-pantai yang mempesona. Dengan menggunakan metode convenience sampling, pemilihan responden didapatkan dari responden yang berdomisili diluar Provinsi Kepulauan Bangka Belitung. Pemilihan tersebut dipilih untuk menghindari jawaban bias dari penduduk lokal yang ada di provinsi tersebut. Terlepas dari kontribusi pulau yang luar biasa terhadap pariwisata, eksplorasi Pulau Belitung dalam penelitian pariwisata telah diobservasi terbatas oleh peneliti (Kusumah et al., 2020). Data dikumpulkan selama tiga puluh hari pada bulan Oktober 2019. Sebanyak 157 kuesioner berhasil didapatkan dan dapat digunakan untuk analisis lebih lanjut.

\section{Pengukuran dan Analisis Data}

Survei yang dilaporkan sendiri dikembangkan dengan menggunakan skala tipe Likert 5 poin $(1=$ sangat tidak setuju; $5=$ sangat setuju). Kuesioner disusun dalam dua bagian. Bagian pertama dari survei meliputi informasi demografis responden (jenis kelamin, usia, pendidikan). Sementara itu, bagian kedua terdiri dari item pengukuran yang mewakili kualitas pengalaman wisata, harga yang dirasakan, dan kepuasan terhadap pulau itu. Item pengukuran diperkenalkan dari penelitian sebelumnya dan diadopsi ulang agar sesuai dengan penelitian ini. Kualitas pengalaman terdiri dari empat variabel (yaitu eskapis, relaksasi, kenikmatan, dan keterlibatan) menggunakan 12 item yang diadopsi (Chen \& Chen, 2010; Moon \& Han, 2019). Tiga item pengukuran digunakan untuk mewakili harga yang dipersepsikan (Han \& Kim, 2009). Kepuasan wisatawan diukur menggunakan tiga item (Chen et al., 2016). Confirmatory factor analysis (CFA) dilakukan dengan menggunakan pendekatan kemungkinan maksimum (maximum likehood) dengan enam variabel secara total (yaitu eskapis, relaksasi, kenikmatan, keterlibatan, persepsi harga yang dirasakan, dan kepuasan wisatawan ke sebuah pulau). Nilai validitas konvergen dikatakan baik jika nilai average variance extracted $(\mathrm{AVE})>0,5$ dan nilai composite reliability $>0,7$ (Hair et al., 2014). Kemudian, nilai validitas diskriminan dianggap baik jika nilai akar kuadrat AVE lebih besar dibandingkan dengan nilai korelasi setiap variabel (Hair et al., 2010). Model fit atau kesesuaian model dianggap cukup baik jika nilai $\mathrm{p}<0,05$; RMSEA < 0,08; CFI, AGI, TLI > 0,9 (Hair et al., 2014). Setelah proses CFA memiliki nilai yang baik, analisis structural equation model (SEM) digunakan untuk menguji hipotesis.

\section{HASIL DAN PEMBAHASAN}

Profil responden ditampilkan pada Tabel 1. 33.1\% responden adalah pria dan $66.9 \%$ adalah wanita. Mayoritas responden berusia 31-40 tahun dan 41-50 tahun (masing-masing $40,8 \%$ dan $44,6 \%$ ) dan memiliki gelar sarjana atau lebih tinggi $(96,8 \%)$. Berdasarkan mayoritas usia dan pendidikan, menyi- ratkan bahwa kunjungan ke Pulau Belitung dimungkinkan didominasi oleh para wisatawan yang memliki tujuan MICE (meetings, incentives, conferences, exhibitions) atau kedinasan, dimana tujuan tersebut dapat melibatkan kualitas pengalaman wisatawan. Sedangkan generasi milenial atau young travelers nampaknya kurang tertarik untuk berwisata ke pulau tersebut.

[Table 1 about here.]

\section{Confirmatory Factor Analysis (CFA)}

Loading factor semua item pengukuran memuaskan, mulai dari 0,697 hingga 0,888 (Tabel 2). Setelah itu, CFA dilakukan dengan menggunakan pendekatan kemungkinan maksimum dengan enam variabel secara total (yaitu eskapis (ES), relaksasi (RI), kenikmatan (KN), keterlibatan (KL), harga yang dirasakan (PH), kepuasan wisatawan (KW) ke sebuah pulau). Hasil CFA disajikan pada Tabel 2. Model menunjukkan kecocokan yang baik (model fit) dengan data (Chi-square = 125,877; $\mathrm{df}=93, \mathrm{p}=0,013$; $\mathrm{RMSEA}=0,048$; $\mathrm{CFI}=0,973$; $\mathrm{GFI}=0,915$; TLI $=0,965)$. Composite Reliability $(\mathrm{CR})$ tersebar antara 0,718 dan 0,840 melampaui batasan yang disarankan, 0,7 (Hair et al, 2014). Nilai-nilai average variance extracted (AVE) juga memuaskan dengan tingkat minimum 0,5 , yang mendukung validitas konvergen. Validitas diskriminan diperiksa serta dibandingkan dengan akar kuadrat AVE dan korelasi. Karena nilai-nilai akar kuadrat AVE semua lebih besar dari korelasi, validitas diskriminan juga dapat diterima (lihat Tabel 3).

$\mathrm{KN}=$ Kesenangan, $\mathrm{KL}=$ Keterlibatan, $\mathrm{ES}=$ Eskapis, $\mathrm{RI}=$ Relaksasi, PH = Persepsi Harga, KW = Kepuasan Wisatawan

[Figure 1 about here.]

[Table 2 about here.]

[Table 3 about here.]

\section{Structural Equation Model (SEM): Pengujian Hipotesis}

SEM digunakan untuk menguji hipotesis. Hasil SEM ditunjukkan pada Tabel 4. Model fit dapat diterima dengan $\chi 2=$ 158,412 , $\mathrm{df}=124, \mathrm{p}<0,05$, RMSEA $=0,042, \mathrm{CFI}=0,972$, $\mathrm{GFI}=0,907$, TLI $=0,966$. Menurut hasil, eskapis (ES) $(\beta=-$ $0,224, \mathrm{CI} 95 \%[-0,418-0,002], \mathrm{p}>0,05)$; kesenangan $(\mathrm{KN})(\beta$ $=0,153$, CI 95\% $[-0,027-0,329], \mathrm{p}>0,05)$; dan relaksasi $(\mathrm{RI})$ $(\beta=0,126$, CI 95\% [-0,094-0,329], $\mathrm{p}>0,05)$ secara statistik tidak berpengaruh signifikan terhadap persepsi harga $(\mathrm{PH})$ yang dirasakan. Hasil ini menolak hipotesis H1, H2, dan H3. Untuk persepsi harga, keterlibatan (KL) adalah satu-satunya anteseden yang signifikan $(\beta=0,240$, CI $95 \%[0,043-0,455]$, $\mathrm{p}$ $<0,05)$, sehingga hipotesis $\mathrm{H} 4$ diterima. Sedangkan, $\mathrm{PH}$ dapat memediasi antara KN dan KW $(\beta=0,038$, CI 95\% [0,006 $0,112], \mathrm{p}<0,05)$; KL dan KW $(\beta=0,060$, CI 95\% [0,003 - 
$0,185], \mathrm{p}<0,05)$; ES dan KW $(\beta=-0,056$, CI 95\% [-0,150 - $0,007], \mathrm{p}<0,05)$. Sehingga hipotesis H6a, H6c, dan H6d dapat diterima. Hanya hubungan antara RI dan $\mathrm{KW}(\beta=0,032, \mathrm{CI}$ $95 \%[-0,013-0,111], \mathrm{p}>0,05)$ yang tidak dapat dimediasi oleh $\mathrm{PH}$, oleh karena itu hipotesis H6b ditolak.

\section{[Table 4 about here.]}

Menerapkan aspek pengalaman, penelitian ini berfokus kepada kualitas pengalaman wisata yang terdiri dari eskapis, relaksasi, kenikmatan, dan keterlibatan, yang memproyeksikan persepsi wisatawan tentang keseluruhan interaksi timbal balik di suatu destinasi kepulauan. Studi ini mengungkapkan temuan yang kontras dibandingkan dengan penelitian sebelumnya, misalnya pada eskapis (Triantafillidou \& Petala, 2016); kesenangan (Amoah et al., 2016); relaksasi (Gallarza et al., 2016) karena dampak kualitas pengalaman pada variabel memanifestasikan hasil berbeda. Variabel-variabel kualitas pengalaman secara langsung tidak signifikan untuk persepsi wisatawan tentang kewajaran harga dalam penelitian ini, kecuali untuk variabel keterlibatan. Hasil tersebut menunjukkan bahwa keterlibatan adalah faktor kunci bagi wisatawan untuk mengevaluasi kewajaran harga. Wisatawan cenderung puas dengan harga yang mereka bayar ketika mereka cukup terlibat dengan proses pengambilan keputusan pada suatu destinasi (Dwyer \& Forsyth, 2011). Wisatawan juga dapat berpikir bahwa mereka memperoleh hak atau kekuatan untuk membuat keputusan saat bepergian, yang dapat dianggap sebagai ganti rugi (harga) mereka. Wisatawan saat ini bukanlah konsumen pasif lagi, akan tetapi co-creator pengalaman di suatu destinasi (Gentile et al., 2007), yang mengarahkan mereka untuk aktif dalam menulusuri destinasi.

Tingkat harga yang dapat diterima mungkin lebih realistis untuk memahami bagaimana wisatawan menilai keseluruhan pengalaman wisata mereka. Ketika para wisatawan berharap untuk menerima pengalaman wisata berkualitas sesuai dengan apa yang mereka bayar, persepsi kognitif dan evaluatif mereka tentang nilai dan harga dapat berubah setelah mengalami pengalaman nyata. Eksplorasi dari kewajaran harga ini dapat menjelaskan tidak hanya interpretasi subyektif wisatawan tentang pengalaman wisata, tetapi juga persepsi objektif mereka bahwa harga yang dibayarkan sesuai dengan pengalaman wisata (Han \& Ryu, 2009).

Persepsi harga secara tidak langsung dapat memediasi kualitas pengalaman wisatawan, kecuali pada relaksasi. Hal tersebut dapat dimungkinkan bahwa terlepas dari kenyataan bahwa wisatawan berpikir harganya tidak masuk akal (mahal atau tidak pantas), mereka masih akan mengevaluasi destinasi secara positif jika mereka dapat berpartisipasi dalam proses pengambilan keputusan. Hal itu pada gilirannya membuat mereka puas dengan pengalaman wisata mereka. Ketika wisatawan menganggap bahwa kunjungan mereka ke destinasi pulau adalah hal yang baik dan mereka membangun citra destinasi positif, kepuasan mereka terhadap pengalaman wisata dapat diperkuat. Demikian pula, wisatawan lebih puas dengan pengalaman wisata ketika mereka berpikir harganya masuk akal dan mereka memiliki citra yang baik. Hal tersebut menggambarkan bahwa wisatawan dengan citra destinasi positif cenderung lebih murah hati dalam mengevaluasi nilai dan kewajaran harga, dan mudah senang dengan pengalaman wisata mereka.

Dalam implikasi praktis, manajemen tingkat pemerintah daerah harus memfasilitasi wisatawan untuk merencanakan jadwal mereka dengan lebih fleksibel dengan memperkuat mobilitas di destinasi pulau. Studi ini mengungkapkan bahwa ketika wisatawan terlibat dan memiliki kontrol atas proses di suatu destinasi pulau, mereka lebih cenderung berpikir bahwa pulau itu menawarkan nilai yang baik, dan harga yang mereka bayar untuk pengalaman wisata mereka masuk akal. Keterlibatan dengan proses ini juga mempengaruhi kepuasan wisatawan dengan pengalaman wisata mereka. Ini mungkin menyiratkan bahwa beberapa bagian yang tidak terkendali dari lingkungan destinasi seperti infrastruktur yang berbeda dapat menyebabkan ketidaknyamanan dan ketidakpuasan wisatawan. Mengambil sistem transportasi sebagai contoh, kemudahan memahami cara menggunakannya dan ketepatan waktu layanan transportasi umum dapat menjadi vital bagi wisatawan untuk mengunjungi tempat-tempat yang mereka inginkan. Dalam hal ini, mobilitas di destinasi pulau adalah salah satu faktor kunci untuk meningkatkan manajemen pariwisata. Manajemen pariwisata pemerintah daerah harus mengatur akses online ke informasi terbaru mengenai layanan transportasi dan memeriksa setiap masalah teknis secara teratur untuk memungkinkan wisatawan memiliki fleksibilitas pergerakan. Dalam kasus Pulau Belitung, jadwal transportasi umum sulit untuk diunduh dan informasinya hanya tersedia dalam bahasa Indonesia. Untuk memenuhi kebutuhan pengunjung internasional, manajer harus memberikan rincian lebih lanjut tentang opsi transportasi (mis. bus, taksi, dan mobil sewaan) dengan terjemahan yang akurat serta dengan desain yang menarik. Memperkuat kualitas sistem transportasi dapat membantu wisatawan untuk dengan mudah berpindah di antara berbagai atraksi dan memiliki rute fleksibel di sebuah pulau sesuai kebutuhan. Praktik ini pada akhirnya akan menciptakan kesan pulau yang layak dikunjungi serta mengarah ke kepuasan dengan pengalaman wisata.

\section{KESIMPULAN}

Studi ini menyelidiki aspek pengalaman wisatawan dimana kualitas mempengaruhi persepsi wisatawan tentang kewajaran harga. Berdasarkan hasil, penelitian ini memberikan kontribusi teoritis penting untuk literatur pariwisata pulau dengan menunjukkan bagaimana pengalaman wisatawan yang dibangun pada destinasi suatu pulau dapat mempengaruhi persepsi mereka. Selain itu, penelitian ini menunjukkan bahwa manajemen pariwisata dan pemerintah daerah dapat memberdayakan wisatawan serta melibatkan mereka dalam proses untuk memberikan kesan bahwa destinasi pulau memberikan nilai yang 
baik dan harga yang sepadan dengan harga yang dibayarkan. Selanjutnya, pemerintah daerah dan masyarakat harus bekerja sama secara erat dalam melestarikan alam dan budaya destinasi pulau serta meningkatkan infrastruktur, misalnya sistem transportasi. Dengan melakukan hal itu, destinasi pulau dapat membuat wisatawan merasa puas dengan pengalaman wisata mereka dan dapat membangun citra positif. Kami berharap bahwa studi ini berkontribusi pada literatur penelitian pariwisata serta pengembangan pariwisata kepulauan.

\section{UCAPAN TERIMA KASIH}

Penulis mengucapkan terima kasih kepada Prof. Ratih Hurriyati yang telah mendukung terhadap penyelesaian artikel ini. Penulis juga ingin mengucapkan terima kasih kepada editor JBMP dan reviewers anonim untuk saran berharga mereka yang membantu memperbaiki artikel ini.

\section{REFERENSI}

Ali, F., Amin, M., \& Ryu, K. (2016). The role of physical environment, price perceptions, and consumption emotions in developing customer satisfaction in Chinese resort hotels. Journal of Quality Assurance in Hospitality \& Tourism, 17(1), 45-70.

Amoah, F., Radder, L., \& van Eyk, M. (2016). Perceived experience value, satisfaction and behavioural intentions. African Journal of Economic and Management Studies.

Bec, A., Moyle, B., Timms, K., Schaffer, V., Skavronskaya, L., \& Little, C. (2019). Management of immersive heritage tourism experiences: A conceptual model. Tourism Management, 72, 117-120.

Boateng, H., Okoe, A. F., \& Hinson, R. E. (2018). Dark tourism: Exploring tourist's experience at the Cape Coast Castle, Ghana. Tourism Management Perspectives, 27, 104-110.

Chen, C.-C., Huang, W.-J., \& Petrick, J. F. (2016). Holiday recovery experiences, tourism satisfaction and life satisfaction-Is there a relationship? Tourism Management, 53, 140-147.

Chen, C.-F., \& Chen, F.-S. (2010). Experience quality, perceived value, satisfaction and behavioral intentions for heritage tourists. Tourism Management, 31(1), 29-35.

Chen, C.-M., Yang, H.-W., Li, E. Y., \& Liu, C.-C. (2015). How does hotel pricing influence guest satisfaction by the moderating influence of room occupancy? International Journal of Hospitality Management, 49, 136-138.

Chen, H., \& Rahman, I. (2018). Cultural tourism: An analysis of engagement, cultural contact, memorable tourism experience and destination loyalty. Tourism Management Perspectives, 26, 153-163.

Dwyer, L., \& Forsyth, P. (2011). Methods of estimating destination price competitiveness: A case of horses for courses? Current Issues in Tourism, 14(8), 751-777.

Gallarza, M. G., Arteaga-Moreno, F., Del Chiappa, G., \& Gil-Saura, I. (2016). Intrinsic value dimensions and the valuesatisfaction-loyalty chain: A causal model for services. Journal of Services Marketing.

Garau-Vadell, J. B., Gutiérrez-Taño, D., \& Díaz-Armas, R. (2019). Residents' support for P2P accommodation in mass tourism destinations. Journal of Travel Research, 58(4), 549-565.

Gentile, C., Spiller, N., \& Noci, G. (2007). How to sustain the customer experience: An overview of experience components that co-create value with the customer. European Management Journal, 25(5), 395-410.

Hair, J. F., Anderson, R. E., Babin, B. J., \& Black, W. C. (2010). Multivariate data analysis: A global perspective (Vol. 7). Upper Saddle River, NJ: Pearson.

Hair, J. F., Gabriel, M., \& Patel, V. (2014). AMOS covariance-based structural equation modeling (CB-SEM): Guidelines on its application as a marketing research tool. Brazilian Journal of Marketing, 13(2).

Han, H., \& Hyun, S. S. (2015). Customer retention in the medical tourism industry: Impact of quality, satisfaction, trust, and price reasonableness. Tourism Management, 46, 20-29.

Han, H., \& Kim, W. (2009). OUTCOMES OF RELATIONAL BENEFITS: RESTAURANT CUSTOMERS'PERSPECTIVE. Journal of Travel \& Tourism Marketing, 26(8), 820-835.

Han, H., \& Ryu, K. (2009). The roles of the physical environment, price perception, and customer satisfaction in determining customer loyalty in the restaurant industry. Journal of Hospitality \& Tourism Research, 33(4), 487-510.

Hosany, S., \& Witham, M. (2010). Dimensions of cruisers' experiences, satisfaction, and intention to recommend. Journal of Travel Research, 49(3), 351-364.

Kaura, V., Prasad, C. S. D., \& Sharma, S. (2015). Service quality, service convenience, price and fairness, customer loyalty, and the mediating role of customer satisfaction. International Journal of Bank Marketing.

Kim, A. K., \& Brown, G. (2012). Understanding the relationships between perceived travel experiences, overall satisfaction, and destination loyalty. Anatolia, 23(3), 328-347.

Kim, H.-W., Xu, Y., \& Gupta, S. (2012). Which is more important in Internet shopping, perceived price or trust? Electronic Commerce Research and Applications, 11(3), 241-252. 
Kim, Y. H., Duncan, J., \& Chung, B. W. (2015). Involvement, satisfaction, perceived value, and revisit intention: A case study of a food festival. Journal of Culinary Science \& Technology, 13(2), 133-158.

Kusumah, E. P., Disman, D., \& Hendrayati, H. (2020). Keterlibatan Merek Terhadap Kepuasan Dan Niat Berkunjung Kembali Konsumen Resort Terpadu. Jurnal Ecodemica: Jurnal Ekonomi, Manajemen, Dan Bisnis, 4(1), 135-145.

Kusumah, E. P., Hurriyati, R., \& Dirgantari, P. D. (2019). Atribut Pemilihan Kualitas Restoran: Citra Merek dan Harga. Jurnal Bisnis Dan Manajemen, 6(2).

Kusumah, E. P., Suryadi, E., \& Dirgantari, P. D. (2020). Prediksi keterikatan tempat: Motivasi, peringkat hotel berbintang, dan kualitas interaksi layanan karyawan. FORUM EKONOMI, 22(1), 152-163.

Lee, T. H., Jan, F.-H., Tseng, C. H., \& Lin, Y. F. (2018). Segmentation by recreation experience in island-based tourism: A case study of Taiwan's Liuqiu Island. Journal of Sustainable Tourism, 26(3), 362-378.

Moon, H., \& Han, H. (2019). Tourist experience quality and loyalty to an island destination: The moderating impact of destination image. Journal of Travel \& Tourism Marketing, 36(1), 43-59.

Murphy, P. E., \& Pritchard, M. (1997). Destination price-value perceptions: An examination of origin and seasonal influences. Journal of Travel Research, 35(3), 16-22.

Prebensen, N. K., Vittersø, J., \& Dahl, T. I. (2013). Value co-creation significance of tourist resources. Annals of Tourism Research, 42, 240-261.

Ryu, K., \& Han, H. (2010). Influence of the quality of food, service, and physical environment on customer satisfaction and behavioral intention in quick-casual restaurants: Moderating role of perceived price. Journal of Hospitality \& Tourism Research, 34(3), 310-329.

Triantafillidou, A., \& Petala, Z. (2016). The role of sea-based adventure experiences in tourists' satisfaction and behavioral intentions. Journal of Travel \& Tourism Marketing, 33(sup1), 67-87.

Zeithaml, V. A. (1988). Consumer perceptions of price, quality, and value: A means-end model and synthesis of evidence. Journal of Marketing, 52(3), 2-22.

Conflict of Interest Statement: The authors declare that the research was conducted in the absence of any commercial or financial relationships that could be construed as a potential conflict of interest.

Copyright (C) 2020 Perdana Kusumah, Hurriyati and Hamsani. This is an open-access article distributed under the terms of the Creative Commons Attribution License (CC $B Y$ ). The use, distribution or reproduction in other forums is permitted, provided the original author(s) and the copyright owner(s) are credited and that the original publication in this journal is cited, in accordance with accepted academic practice. No use, distribution or reproduction is permitted which does not comply with these terms. 


\section{LIST OF FIGURES}

1 Hasil Konstruk Penelitian . . . . . . . . . . . . . . . . . . . . . . . . . . 




FIGURE 1 | Hasil Konstruk Penelitian 


\section{LIST OF TABLES}

Profil Responden $($ sampel $=157) \ldots \ldots \ldots \ldots$

Loadings Factor, Nilai AVE, dan Nilai CR . . . . . . . . . . . . . . . . . . . . . . . . 11

Validitas Diskriminan . . . . . . . . . . . . . . . . . . . . . . . . . 12

4 Nilai Standardized Coefficient, Bias Corrected (BC) Lower-Upper, Significance dan Keterangan . . . . . . . . . . 13 
TABLE 1 | Profil Responden (sampel = 157)

\begin{tabular}{llll}
\hline \multirow{3}{*}{ Jenis Kelamin } & Pria & Frekuensi & Persentase \\
\cline { 2 - 3 } Usia & Wanita & 52 & 33,1 \\
& $<20$ tahun & 0 & 66,9 \\
& 21-30 tahun & 6 & 0 \\
& 31-40 tahun & 64 & 3,8 \\
& 41-50 tahun & 70 & 40,8 \\
& Pendidikan tahun & 17 & 10,8 \\
& SMA/Sederajat & 0 & 0 \\
& Diploma & 5 & 3,2 \\
& Sarjana & 30 & 19,1 \\
& Pasca Sarjana & 122 & 77,7 \\
\hline
\end{tabular}


TABLE 2 | Loadings Factor, Nilai AVE, dan Nilai CR

\begin{tabular}{llll}
\hline & Loadings & AVE & CR \\
ph1 & 0,724 & & \\
ph2 & 0,906 & 0,641 & 0,897 \\
ph3 & 0,761 & & \\
kw1 & 0,709 & & \\
kw2 & 0,741 & 0,543 & 0,837 \\
kw3 & 0,759 & & \\
kn1 & 0,853 & & \\
kn2 & 0,762 & 0,705 & 0,912 \\
kn3 & 0,899 & & \\
kl1 & 0,841 & & \\
kl2 & 0,655 & 0,574 & 0,838 \\
kl3 & 0,765 & & \\
es1 & 0,919 & & \\
es2 & 0,946 & 0,754 & 0,920 \\
es3 & 0,722 & & \\
ri1 & 0,840 & & \\
ri2 & 0,816 & 0,552 & 0,821 \\
ri3 & 0,534 & & \\
\hline
\end{tabular}


TABLE 3 | Validitas Diskriminan

\begin{tabular}{lllllll}
\hline & $\mathrm{KN}$ & $\mathrm{KL}$ & $\mathrm{ES}$ & $\mathrm{RI}$ & $\mathrm{PH}$ & $\mathrm{KW}$ \\
$\mathrm{KN}$ & 0,840 & & & & & \\
$\mathrm{KL}$ & 0,228 & 0,758 & & & & \\
$\mathrm{ES}$ & 0,025 & $-0,009$ & 0,868 & & & \\
$\mathrm{RI}$ & $-0,107$ & $-0,125$ & 0,364 & 0,743 & & \\
$\mathrm{PH}$ & 0,189 & 0,251 & $-0,175$ & 0,000 & 0,801 & \\
$\mathrm{KW}$ & $-0,05$ & 0,322 & $-0,052$ & $-0,047$ & 0,247 & 0,737
\end{tabular}


TABLE 4 | Nilai Standardized Coefficient, Bias Corrected (BC) Lower-Upper, Significance dan Keterangan

\begin{tabular}{llllll}
\hline & $\beta$ & $\mathrm{BC}(\mathrm{Cl} 95 \%)$ & $\mathrm{S}$. & Ket. \\
$\mathrm{KN} \rightarrow$ & $\mathrm{PH}$ & 0,153 & $-0,027-0,329$ & $\mathrm{p}>0,05$ & Ditolak \\
$\mathrm{KL} \rightarrow$ & $\mathrm{PH}$ & 0,240 & $0,043-0,455$ & $\mathrm{p}<0,05$ & Diterima \\
$\mathrm{ES} \rightarrow \mathrm{PH}$ & $-0,224$ & $-0,418-0,002$ & $\mathrm{p}>0,05$ & Ditolak \\
$\mathrm{RI} \rightarrow \mathrm{PH}$ & 0,126 & $-0,094-0,329$ & $\mathrm{p}>0,05$ & Ditolak \\
$\mathrm{PH} \rightarrow \mathrm{KW}$ & 0,252 & $0,055-0,462$ & $\mathrm{p}<0,01$ & Diterima \\
$\mathrm{KN} \rightarrow \mathrm{PH} \rightarrow$ & 0,038 & $0,006-0,112$ & $\mathrm{p}<0,05$ & Diterima \\
$\mathrm{KW}$ & & & & \\
$\mathrm{KL} \rightarrow \mathrm{PH} \rightarrow$ & 0,060 & $0,003-0,185$ & $\mathrm{p}<0,05$ & Diterima \\
$\mathrm{KW}$ & & & & \\
$\mathrm{ES} \rightarrow \mathrm{PH} \rightarrow$ & $-0,056$ & $-0,150--0,007$ & $\mathrm{p}<0,05$ & Diterima \\
$\mathrm{KW}$ \\
$\mathrm{RI} \rightarrow \mathrm{PH} \rightarrow$ & 0,032 & $-0,013-0,111$ & $\mathrm{p}>0,05$ & Ditolak \\
$\mathrm{KW}$ & & & & \\
\hline
\end{tabular}

